\title{
Some Afterthoughts - or Looking Back
}

\author{
Horst Kächele ${ }^{1}$ \\ International Psychoanalytic University (IPU)
}

The relationship of "psychoanalysis and language" was in the center of many theoretical and clinical discussions ever since Freud (1916/17) had declared:

Nothing takes place in a psycho-analytic treatment but an interchange of words between the patient and the analyst. The patient talks, tells of his past experiences and presents impressions, complains, confesses his wishes and his emotional impulses. The doctor listens, tries to direct the patient's processes of thought, exhorts, forces his attention in certain directions, gives him explanations and observes the reaction of understanding or rejection which he in this way provokes in him (p. 17).

In contrast to the clear recognition of psychoanalysis as discursive activity - as Lacan (1953) espoused it succinctly - for quite a time the main stream activity on the relation of psychoanalysis and language was focused on Freud's theory of symbols. Language and the development of the ego was a favourite topic in the New York study group on linguistics (Edelheit, 1968). As Freud had developed his own rather idiosyncratic way of understanding symbols, some conceptual work with the different usage of the term symbol had to be done. Victor Rosen in his paper on "Sign Phenomena and their relationship to unconscious meaning" (1969) demonstrates that the work of the psychoanalyst can be conceptualized as a process of differentiating conventional symbols from sign phenomena. Understanding meaning by common sense has to be completed by understanding the additional unconscious meaning any concrete piece of verbal material may carry. The technical rule for the analyst of evenly hovering attention is directed to just this process. Listening to his patient's associations the analyst receives the conventional meaning of what he listens to. Suspending his reaction to this level of meaning he then tries to understand potential meanings beyond the everyday meaning. By interpreting the analyst usually uses a perspective that is not immediate in his patient's view.

However, Forrester (1980) expressed, in his introduction of his book "Language and Origin of Psychoanalysis", astonishment that there were only a few treatises on psychoanalysis, which dealt directly with the role of language in the course of treatment

${ }^{1}$ Correspondence concerning this article should be addressed to Prof. Horst Kächele, International Psychoanalytic University (IPU), Stromstr. 2-3. 10555 Berlin, Germany. E-mail: horst.kächele @ipu-berlin.de.

Language and Psychoanalysis, 2016, 5 (2), 81-87

http://dx.doi.org/10.7565/landp.v5i2.1562 
(p. X). Detailed studies concerning "spoken language in the psychoanalytical dialogue" were just beginning to blossom in the eighties of the last century (Kächele, 1983).

Praising the Freudian dictum many a times psychoanalysts - often unintentionally - have been followers of the philosopher Austin (1962), who in his theory of speech acts, proceeds from the observation that things get done with words. In the patterns of verbal action, there are specific paths of action available for interventions to alter social and psychic reality. In psychoanalysis, writes Shapiro (1999), "the prolonged interaction between patient and analyst provides numerous opportunities for redundant expression of what is considered a common small set of ideas in varying vehicles and at various times, designed to get something done or to re-create an old pattern" (p. 111). However, speech, if it is to become effective as a means of action, is dependent on the existence of interpersonal obligations that can be formulated as rules of discourse. These rules of discourse depend partly on the social context of a verbal action (those in a court of law differ from those in a conversation between two friends), and conversely, a given social situation is partly determined by the particular rules of discourse. Expanding this observation psychoanalytically, one can say that the implicit and explicit rules of discourse help to determine not only the manifest social situation, but also the latent reference field, that is transference and countertransference.

If the discourse has been disturbed by misunderstandings or breaches off the rules, metacommunication about the preceding discourse must be possible which is capable of removing the disturbance. For example, one of the participants can insist on adherence to the rule (e.g., "I meant that as a question, but you haven't given me an answer!"). In such metacommunication, the previously implicit rules which have been broken can be made explicit, and sometimes the occasion can be used to define them anew, in which case the social content and, we can add, the field of transference and countertransference can also change.

The compulsion arises from the fact that analyst and patient have entered into a dialogue and are therefore subject to rules of discourse, on which they must be in at least partial (tacit) agreement if they want to be in any position to conduct the dialogue in a meaningful way. It is in the nature of a question that the person asking it wants an answer and views every reaction as such. The patient who is not yet familiar with the analytic situation will expect the conversation with the analyst to follow the rules of everyday communication.

The exchange process between the patient's productions, loosely called "free associations", and the analyst's interventions, loosely called "interpretations", most fittingly may be classified as a special sort of dialogue. The analyst's interventions encompass the whole range of activities to provide a setting and an atmosphere that allows the patient to enter the specific kind of analytic dialogue: 
If any kind of meaningful dialogue is to take place, each partner must be prepared (and must assume that the other is prepared) to recognize the rules of discourse valid for the given social situation and must strive to formulate his contributions accordingly (Thomä \& Kächele, 1994b, p. 248).

The special rules of the analytic discourse thus must be well understood by the analysand lest he or she waste the time not getting what he or she wants. Therefore she or he has to understand that the general principle of cooperation is supplemented by a specific additional type of meta-communication on part of the analyst. As we have already pointed out the analyst's interventions have to add a surplus meaning beyond understanding the discourse on the plain everyday level.

How does one add a surplus meaning? Telling a joke is a good case for working with a surplus meaning not manifest in the surface material. Jokes have a special linguistic structure and most often work with a combination of unexpected material elements and special tactic of presentation. Reporting clinical examples from the literature Spence et al. (1994) suggest that the analyst is always scanning the analytic surface in the context of the two-person space, consciously or preconsciously, weighing each utterance against the shifting field of connotations provided by (a) the course of the analysis; (b) his or her own set of associations; and (c) the history of the analysand's productions (p. 45). An experimental way to detect the generation of such ad-on meanings was Meyer's (1988) effort via post-session free associative self-reports to find out "what makes the psychoanalyst tick".

For such questions, which are basic for the psychoanalytic enterprise the development of conversational and discourse analytical methods was crucial moving the pragmatic use of language as speech on empirical grounds. When Sacks et al. (1974) proposed a "simplest systematics for the organization of turn-taking behavior in conversation" it was obvious that such tools would be of high relevance to psychotherapy as an exquisite dialogic enterprise. Although Mahony (1977) gave psychoanalytic treatment a place in the history of discourse, Labov and Fanshel (1977) probably were the first to apply such concepts to empirical investigation of psychotherapy sessions. In Germany the linguist Klann (1977) connected "psychoanalysis and the study of language" no longer focusing on the traditional discussion on symbols but focusing on the pragmatic use of language as therapeutic tool exemplified by role of affective processes in the structure of dialogue (Klann, 1979).

In this arena many things that take place in the relationship between patient and analyst at the unconscious level of feelings and affects cannot be completely referred to by name, distinguished, and consolidated in experiencing (see Bucci, 1995). Intentions that are prelinguistic and that consciousness cannot recognize can only be imprecisely verbalized. Thus in fact much more happens between the patient and analyst than just an exchange of words. Freud's "nothing else" must be understood as a challenge for the patient to reveal 
his thoughts and feelings as thoroughly as possible. The analyst is called upon to intervene in the dialogue by making interpretations using mainly linguistic means.

Of course, it makes a big difference if the analyst conducts a dialogue, which always refers to a two-sided relationship, or if he makes interpretations that expose the latent meanings in a patient's quasi-monological free associations. Although it has become customary to emphasize the difference between the therapeutic interview and everyday conversation (Leavy, 1980), we feel compelled to warn against an overly naive differentiation since everyday dialogues often are:

characterized by only apparent understanding, by only apparent cooperation, by apparent symmetry in the dialogue and in the strategies pursued in the conversation, and that in reality intersubjectivity often remains an assertion that does not necessarily lead to significant changes, to dramatic conflicts, or to a consciousness of a "pseudounderstanding"...In everyday dialogues something is acted out and silently negotiated that in therapeutic dialogues is verbalized in a systematic manner (Klann, 1979, p. 128).

Flader and Wodak-Leodolter (1979) collected these first German studies on processes of therapeutic communication. Some years later these researchers discovered the rich material available at the Ulm Textbank (Flader et al. 1982). This was probably not surprising because the availability of original transcripts for linguists was at the time very limited. Amongst others, the opening phase of Amalia X's treatment, that phase of familiarizing the patient into the analytical dialog and the transition from day to day discourse into the analytical discourse, was examined (Koerfer and Neumann 1982): Towards the end of the second (recorded) session Amalia X complains about the unusual dialogic situation in the following way: 'alas, I find this is quite a different kind of talk as I am used to it'.

This kind of difficulty has been described by Lakoff (1981) succinctly: "The therapeutic situation itself comprises a context, distinct from the context of 'ordinary conversation', and that distinction occasions ambiguity and attendant confusion" (p. 7). In fact we are dealing with a learning situation comparable to learning a foreign language though less demanding:

If in fact psychotherapeutic discourse were radically different in structure from ordinary conversation, we should expect something quite different: a long period of training for the patient, in which frequent gross errors were made through sheer 
ignorance of the communicative system, in which he had time after time to be carefully coached and corrected (Lakoff, 1981, p. 8).

This perspective supports our maxim of the treatment technique: as much day-to-day dialogue as necessary to correspond to the safety needs of the patient, to allow this learning process and as much analytical dialogue as possible to further the exploration of unconscious meanings in intra and interpersonal dimensions (Thomä \& Kächele, 1994b, p. $251 \mathrm{ff})$.

In the following years, the "linguistic turn", the inclusion of pragma-linguistic tools into the study of the psychoanalytical discourse, gained considerable momentum (Russell 1989, 1993). For example, Harvey Sacks (1992) described "conversational analysis" (CA) that put "coherence" in the center, which also plays a central role in attachment research. Lepper and Mergenthaler (2005) could show in a group therapy setting and in a psychodynamic short therapy (Lepper \& Mergenthaler 2007) that the "topic coherence" stands in a close connection with clinically important moments, insights and changes.

Systematic investigations on the special conversational nature of the psychoanalytic technique have become more diversified. The linguist Streeck (1989) illustrates how powerful conversational technique were even in identifying prognostic factors for shared focus formulation in short term therapy related to positive outcome where psychometric instruments failed. The role of metaphor in therapeutic dialogues has developed into a field of its own (Spence, 1987; Buchholz, 2007; Casonato and Kächele, 2007). Intersubjective conceived treatment research enlarges the empirical frame by including dimensions of conversational practice, narrative representation and use of metaphor. Is it too far reached to connect the development of the relational perspective in psychoanalysis with the rise of narrative treatment research focusing on what happens between patient and analyst in great details as Buchholz (2006, p. 307) does?

The mechanism of psychoanalytic interpretation had been the object of an early discourse-analytic case study by Flader and Grodzicki (1982) recently followed by a larger sample studied by Peräkylä (2004). The issue whether discourse in psychoanalysis proper is different from discourse in psychotherapy might be no longer in the center of interest. The more empirical material is studied the less these differences show up. Patients and their analysts display a range of conversational strategies in the diverse therapeutic situations as Streeck (2004) has illustrated.

The contributions of the Berlin study group on conversational analysis have shouldered the unfinished task to detailing what goes on in psychotherapeutic sessions on a level that will certainly enrich our understanding. 


\section{References}

Austin, J. L. (1962). How to do things with words. Oxford: Clarendon Press.

Bucci, W. (1995). The power of the narrative. A multiple code account. In J. Pennebaker (Ed.), Emotion, disclosure and health. Washington, D.C.: American Psychological Association.

Buchholz, M. B. (2006). Konversation, Erzählung, Metapher. Der Beitrag qualitativer Forschung zu einem relationalen Paradigma der Psychoanalyse (Conversation, narration,metaphor. The contribution of qualitative research for the relational paradigm of psychoanalysis). In M. Altmeyer \& H. Thomä (Eds.), Die vernetzte Seele. Die intersubjektive Wende in der Psychoanalyse (pp. 282-313). Stuttgart: Klett-Cotta.

Buchholz, M. B. (2007). Listening to words, seeing images. Metaphors of emotional movement. International Forum of Psychoanalysis, 16, 164 - 176.

Casonato, M., \& Kächele, H. (2007). Le metaphore di Amalie X. In H. Kächele \& H. Thomä (Eds.), La ricerca in psicoanalisi. Lo studio del “caso empirico” (pp. 195204). Urbino: Quattro Venti.

Edelheit, H. (1968). Language and the development of the ego. Journal of the American Psychoanalytic Association, 16, 113-122.

Flader, D., \& Grodzicki, W. D. (1982). Die psychoanalytische Deutung. Eine diskursanalytische Fallstudie (The psychoanalytic interpretation. A discourseanalytic case study). In D. Flader, W. D. Grodzicki, \& K. Schröter (Eds.), Psychoanalyse als Gespräch (Psychoanalysis as discourse) (pp. 138-193). Frankfurt am Main: Suhrkamp.

Flader, D., \& Wodak-Leodolter, R. (1979). Therapeutische Kommunikation (Therapeutic communication). Königstein: Scriptor.

Flader, D., Grodzicki, W. D., \& Schröter, K. (Eds.). (1982). Psychoanalyse als Gespräch (Psychoanalysis as discourse). Frankfurt am Main: Suhrkamp.

Forrester, J. (1980). Language and the origins of psychoanalysis. London: Macmillan.

Freud, S. (1916/17). Introductory lectures on psycho-analysis. Standard Edition, 15-16.

Kächele, H. (1983). Sprache im psychoanalytischen Dialog (Language in the psychoanalytic dialogue). Texte - Zur Theorie und Praxis der Psychoanalyse, 3, 309-327.

Klann, G. (1977). Psychoanalyse und Sprachwissenschaft (Psychoanalysis and science of language). In F. Hager (Ed.), Die Sache der Sprache (The issue of language) (pp. 129-167). Stuttgart: Metzler`sche Verlagsbuchhandung.

Klann, G. (1979). Die Rolle affektiver Prozesse in der Dialogstruktur (The role of affective processes in the struture of dialogue). In D. Flader \& R. Wodak-Leodolter (Eds.), Therapeutische Kommunikation (pp. 117-155). Königstein: Scriptor.

Koerfer, A., \& Neumann, C. (1982). Alltagsdiskurs und psychoanalytischer Diskurs. Aspekte der Sozialisierung der Patienten in einen "ungewöhnlichen" Diskurstyp (Everyday discourse and psychoanalytic discourse. Aspects of socialization into an 'unusual' type of discourse). In D. Flader, W.-D. Grodizcki, \& K. Schröter (Eds.), Psychoanalyse als Gespräch. Interaktionsanalytische Untersuchungen über Therapie und Supervision (pp. 96-137). Frankfurt: Suhrkamp.

Labov, W., \& Fanshel, D. (1977). Therapeutic discourse. Psychotherapy as conversation. New York: Academic Press. 
Lacan, J. (1953). Fonction et champ de la parole et du langage en psychanalyse. In J. Lacan (Ed.), Écrits (pp. 237-322). Paris: Éditions du Seuil.

Lakoff, R. T. (1981). The rationale of psychotherapeutic discourse. Berkeley: mimeo.

Leavy, S. A. (1980). The psychoanalytic dialogue. New Haven: Yale University Press.

Lepper, G., \& Mergenthaler, E. (2005). Exploring group process. Psychotherapy Research, 15, 433-444.

Lepper, G., \& Mergenthaler, E. (2007). Therapeutic collaboration: How does it work. Psychotherapy Research, 17, 576-587.

Mahony, P. J. (1977). The place of psychoanalytic treatment in the history of discourse. Psychoanalysis and Contemporary Thought, 2, 77-111.

Meyer, A. E. (1988). What makes psychoanalysts tick? In H. Dahl, H. Kächele, \& H. Thomä (Eds.), Psychoanalytic process research strategies (pp. 273-290). Berlin Heidelberg New York London Paris Tokyo: Springer.

Peräkylä, A. (2004). Making links in psychoanalytic interpretations: A conversational analytic perspective. Psychotherapy Research, 14(3), 289-307.

Rosen, V. H. (1969). Sign phenomena and their relationship to unconscious meaning. International Journal of Psychoanalysis, 50, 197-207.

Sacks, H. (1992). Lectures in conversation. Oxford: Blackwell.

Sacks, H., Schegloff, E. A., \& Jefferson, G. (1974). A simplest systematics for the organization of turn-taking behavior in conversation. In J. N. Schenkein (Ed.), Studies in the organization of conversational interaction (pp. 5-56). New York: Academic Press.

Shapiro, T. (1999). The representational word and the linguistic idiom. In P. Fonagy, A. M. Cooper, \& R. S. Wallerstein (Eds.), Psychoanalysis on the move: The work of Joseph Sandler (pp. 105-117). London, New York: Routledge.

Spence, D. P. (1987). The Freudian metaphor. Towards paradigm change in psychoanalysis. New York London: W. W. Norton.

Spence, D. P., Mayes, L. C., \& Dahl, H. (1994). Monitoring the analytic surface. Journal of the American Psychoanalytic Association, 42, 43-64.

Streeck, S. (1989). Die Fokusierung in Kurzzeittherapien. Eine konversationsanalytische Studie (Focusing in short term psychotherapies). Opladen: Westdeutscher Verlag.

Streeck, U. (2004). Auf den ersten Blick - Psychotherapeutische Beziehungen unter dem Mikroskop (On a first glance - Psychotherapeutic relationships under the microscope). Stuttgart: Klett-Cotta.

Thomä, H., \& Kächele, H. (1994b). Psychoanalytic practice. vol. 2: Clinical studies. New York: Jason Aronson. 